\title{
THE NEED TO DEFINE 'ABANDONED HOUSING PROJECT' IN PENINSULAR MALAYSIA: AN ANALYSIS
}

\author{
Nuarrual Hilal Md. Dahlan*
}

\begin{abstract}
Although there are administrative definitions of 'abandoned housing project' in Peninsular Malaysia issued by the Division of Supervision and Enforcement, Ministry of Housing and Local Government (MHLG), the definitions given, seems, have not been satisfactory. Further there is no statutory nor legal definition over the same resulting in certain confusion and uncertainty on the true meaning of 'abandoned housing project' occurring in Peninsular Malaysia. This article discusses the definitions and analyzes their perimeters and possible meanings towards achieving a better definition either legal, statutory or administrative definition of 'abandoned housing project,'
\end{abstract}

\section{INTRODUCTION}

Abandoned housing projects are appalling events that occur in housing industry in Malaysia. Even though, the housing industry has developed throughout the nation since Independence day, a negative

Lecturer, Department of Law, University Utara Malaysia. 
phenomenon ${ }^{1}$ that keeps recurring, is abandoned housing projects. As a result, many housing projects have been identified as being abandoned and have come to a halt. Likewise, additional costs are required to complete the outstanding and remaining construction of the abandoned housing units. Although housing, planning and construction laws and regulations have been passed by Parliament with the purpose of controlling and regulating the housing development industry in Peninsular Malaysia, it is regretted that, this catastrophe-abandoned housing projects are still common and persisting until today.

The objective of this article is to discuss the meaning and definition of abandoned housing project, insofar as the situations in Peninsular Malaysia is concerned. The definition which would be mainly highlighted and legally analyzed would be the one provided by the Division of Enforcement and Supervision, Ministry of Housing and Local Government (MHLG).

\section{THE IMPORTANCE OF LEGAL DEFINITION OF ABANDONED HOUSING PROJECT}

The definition of abandoned housing project should have been legally provided for and statutorily interpreted. It is suggested that the administrative definitions given by the Division of Supervision and Enforcement, MHLG may be used as the statutory and legal definition of abandoned housing projects. In addition thereto, statutory provision especially the Housing Development (Control and Licensing) Act 1966 and its Regulations made thereunder (Act 118), if it were to be passed, must define the stage or point in time when abandonment is said to occur.

The word 'phenomenon' means inter alia, 'a fact or an event in nature or society especially one that is not fully understood.' See AS Hornby, Oxford Advanced Learner's Dictionary of Current English, Sixth Edition, Sally Wehmeir (ed.), Oxford University Press, Oxford, 2001, p. 872. Further, according to Oxford Fajar Advanced Learner's EnglishMalay Dictionary, 'phenomenon' means, inter alia, 'fact or occurrence, especially in nature or society, that can be perceived by the sense.' See AS Horbny, Oxford Fajar Advanced Learner's English-Malay Dictionary, Asmah Haji Omar (penterjemah dan Editor Umum), Penerbit Fajar Bakti Sdn. Bhd, Shah Alam, 2000, p. 1368. 
For example, abandonment may occur if certain stages and progress of the housing development/construction which is being carried out by the developer has been terminated or whre the developer fails to comply with the statutory duty to submit the progress reports to MHLG for certain months.

The purpose of formulating this legal and statutory definition of abandoned housing is to guard against any abuse of duty and power ${ }^{2}$ by the developer concerned. This can be illustrated as follows- the developer must complete the construction of the projects within the statutory period of $24^{3}$ or $36^{4}$ months. Based on this obligation, they shall not delay construction activities beyond this period. Otherwise, they have to pay damages. ${ }^{5}$ However, there are cases where, the developers had delayed the construction. This phenomenon, may be due to their mismanagement, siphoning of funds and other mala fide hidden agendas to the detriment of the purchasers' interests. Although the MOF, inter alia, states that, if there is no construction activity within six (6) or more months, the project would be considered abandoned) ${ }^{6}$ yet, the developers concerned, may

2 'Duty and power' means all general duties and powers of the developer, either legal, statutory and administrative as enshrined in the Housing Development (Control and Licensing) 1966 (Act 118) and its regulations made thereunder and duties and powers prescribed by MHLG.

$3 \quad$ Provided in cl 23(1) of Schedule G, Housing Development (Control and Licensing) Regulation 1989-Sale and Purchase Agreement (Land and Building).

$4 \quad$ Provided in cl 26(1) of Schedule H, Housing Development (Control and Licensing) Regulation 1989_-Sale and Purchase Agreement (Building Intended For Sub-division).

5 If the developer (vendor) fails to deliver vacant possession of the said parcel within this stipulated period, they shall be liable to pay the purchaser liquidated damages calculated from day to day at the rate of ten per centum (10\%) per annum of the purchase price from the expiry date of delivery of vacant possession until the date of the purchaser takes vacant possession of the said parcel. See cl 26(2) of Schedule H, Housing Development (Control and Licensing) Regulation 1989_-Sale and Purchase Agreement (Building Intended For Sub-division and cl 23(2) of Schedule G, Housing Development (Control and Licensing) Regulation 1989_-Sale and Purchase Agreement (Land and Building).

$6 \quad$ Part of the definition of abandoned housing project for year 2006. See in the Ministry of Housing and Local Government, Laporan Senarai 
argue that, as the time period for them to complete the houses is still available and outstanding, i.e the period of 24 or 36 months are still remaining, MHLG shall not have any legal standing or locus to take any action or interfere with their business, let alone to declare the projects abandoned. Further more, the developers may emphasize that, even if they could not complete the construction within the statutory period, MHLG has no legal right to take action against them, as they have agreed and undertook to pay the statutory damages for late delivery of vacant possession to the purchasers. ${ }^{7}$ This is the legal predicament. It is difficult for MHLG or the purchasers or the rehabilitating agencies to take over or go into the project for revival soonest possible to avoid further problems, unless the developers concerned admits this problem and surrender the projects to MHLG to resume the construction. ${ }^{8}$ The problem may also give rise to further 'headache' and troubles in that, dispute and tussle may ensue between purchasers, local authorities, technical agencies, contractors, architects, engineers, state authorities, end financiers and the developers concerned. ${ }^{9}$ This dispute could to a certain extent, lead to litigation. ${ }^{10}$ If this were to happen, it would certainly prolong the plan for rehabilitation to an indefinite period of time. Yet the rehabilitation of the project remains stalled. Due to the long delay, to rehabilitate, the materials and physical state of the uncompleted building could have been damaged, becomes unsuitable for human habitation/occupation and the increasing costs and expenses needed to repair and replace them will increase. ${ }^{11}$

Projek Perumahan Terbengkalai Dari Tahun 1990-Jun 2005 (List of Abandoned Housing Projects From Year 1990-June, 2005), 2006, p. 1.

Interview with Mr. Tomadan Johari, the then Deputy Secretary General (Development), now as the Deputy Secretary General (Operation), MHLG, Pusat Bandar Damansara, on 22 December 2005. See for example Taman Han Chiang, Lot 2343, PB6, NED, Penang (Lam Chew Development Sdn. Bhd), file No 340/D/(547)/E and KPKT/BL/ 19/547-2.

$9 \quad$ For example Taman Showkat, Lot 2219, Mukim 13, NED, Penang (Showkat Industry \& Realty Sdn. Bhd). See file No KPKT/08/824//337 Jil II.

$10 \quad$ Ibid.

11 See for example Taman Yew Lean, Lot Number 664, Section 2, NED, Penang. (Yew Lean Development Sdn Bhd). File No KPKT/08/824/365. 
Further, by having the official, statutory and legal definition, the rehabilitation of the abandoned projects could be expedited and this would smooth the way for the due completion of the project without more ado. It follows that once certain project is officially, statutorily and legally defined as 'abandoned housing project,' MHLG or the purchasers or the rehabilitating parties can without delay, after getting approval and endorsement from MHLG, make an official declaration announcing that such a particular housing development be revived. ${ }^{12}$ Thus, the project so abandoned can immediately be vested in MHLG or purchasers or the rehabilitating parties' control through pre-emptive power. The defaulting developer, then, has no more power and right to develop the project. Following this, a new supplementary rehabilitation legal regime is required to guide and control the process of rehabilitation. The laws and statutory provisions granting necessary powers to MHLG or the purchasers or the rehabilitating parties to take over the abandoned housing projects and to exercise necessary actions in order to rehabilitate them, will serve MHLG with formidable statutory vesting and moratorium mechanisms against any interfering and unduly action, either legal or non-legal, from recalcitrant parties who can jeopardize the whole rehabilitation processes.

The endorsement and certification that a particular housing project is an abandoned housing project, by MHLG, is also vital as there may be purchasers who may wish to terminate and nullify the sale and purchase agreements with such abandoned housing developer for the purpose of buying other new property, applying for the reduction of the monthly installment payment from the end-financiers, obtaining new loan from the end-financiers, requesting the end-financiers to stop making further release and disbursement of the loan funds to the defaulting abandoned developer for preserving the balance fund unreleased from being dishonestly manipulated by the developer and their architect to the detriment of the pecuniary, non-pecuniary and proprietary interests of

12 See also s 11(1)(d) of Act 118, where the minister could invoke this provision in order to certify that a particular housing developer has abandoned the project. See also s 7 (g) of Act 118, where the housing developer is imposed, a statutory duty, by this section to inform immediately the Housing Controller that he is unable to meet his obligations to the purchasers at any stage of the housing development before the issuance of the CF. It is submitted that, this 'inability' also would include when the project is abandoned. 
the purchasers, supporting their applications to rent public or government/ employers' houses and for the withdrawal of funds from the housing account of the Employee Provident Fund (EPF).

Further, the categorization of the problematic projects as falling under the definition of abandoned housing projects is paramount, as distinct from the 'late project' and the 'sick project,' as it helps MHLG and the rehabilitating agencies to step into the shoe of the abandoned housing developers and replace them for the purpose of rehabilitating and reviving the project so abandoned and for focusing and undertaking special initiatives, to rehabilitate them and to help the fate of the aggrieved purchasers.

\section{THE DEFINITION}

Ironically however, there has not yet been any official, legal or judicial definition of 'abandoned housing project.' ${ }^{13}$ Be that as it may, the current practical definition for abandoned housing project occurring in Peninsular Malaysia (the 2006's definition), for the purpose of facilitation and administration, has been given by the Division of Supervision and Enforcement, Ministry of Housing and Local Government (MHLG) and is defined as follows:

a) Construction activities on site of the housing construction project have stopped for 6 (six) months or more consecutively, after the expiry of the Sale and Purchase Agreement (S \& P) executed by the developer and the purchaser or;

b) The developer has been put under the control of the Official Receiver and the Housing Controller is of the opinion that such developer cannot duly proceed with the execution of its obligations as a developer. ${ }^{14}$

$13 \quad$ Nuarrual Hilal Md. Dahlan, Projek Perumahan Terbengkalai: Fenomena, Masalah dan Penyelesaian-Satu Kajian Kes di Daerah Timur Laut, Pulau Pinang, Unpublished Master of Law Thesis, 2001, Universiti Kebangsaan Malaysia, p. 15.

$14 \quad$ Ministry of Housing and Local Government, Laporan Senarai Projek Perumahan Terbengkalai Dari Tahun 1990-Jun 2005 (List of Abandoned Housing Projects From Year 1990-June, 2005), 2006, p. 1. This is the current definition of 'abandoned housing projects.' 
Before the above definition, there were various definitions of the same. For example, the definition in the year 2000 was as follows:

a) Construction and development works on site of the project that has been terminated for the preceding 6 months or more. Such termination has either occurred consecutively or occurred during the period within which the project must be completed or beyond the required completion period. Completion period means the period within which the developer has to complete the construction of the housing units. For the landed property, the completion period is 24 months calculated from the date of the sale and purchase agreement being executed, whilst for flats the completion period is 36 months from the date of the execution of the sale and purchase agreement; or,

b) Within the said duration of 6 (six) months, the developers concerned had been wound up and has been put under the control of the Official Receiver ${ }^{15}$ and the housing controller is of the opinion that a particular housing developer fails to carry out their obligation as a developer.

Prior to year 2000, the definition was as follows: ${ }^{16}$

a) Construction and development works on site of the housing project, have been terminated for 6 (six) months or more

15 Attached to the Insolvency Department under the Prime Minister Department. The function of this officer is to preserve and accumulate the assets and money of the debtors, pending the determination and distribution of the assets and money to secured and unsecured creditors in order to settle up the debts owed by the debtors. See: http://www.bheuu.gov.my/jim/senaraicawangan.shtml.

16 Ministry of Housing and Local Government, Senarai Projek Perumahan Swasta Yang Terbengkalai Tahun 1999, 2000, p. 1. According to Zulfakar bin Rahmat, this definition was the definition for abandoned housing projects issued by the Division of Enforcement and Supervision, Ministry of Housings and Local Government for the 1990s. See Zulfakar bin Rahmat, Projek Perumahan Terbengkalai di Malaysia: Masalah dan Penyelesaiannya, Thesis for Master of Public Administration, Universiti Malaya, 1994, p. 26. 
continuously, regardless of whether the termination occurred during the period within which the project shall be completed by the developer or beyond such period, as which has been stipulated in the sale and purchase agreement executed by the developer and the purchasers; or

b) the developer admits that he is unable to proceed with the project; or

c) the Housing Controller is of the opinion that the developer cannot carry out their obligations as a fit developer.'

While the definition before 1990s, was: ${ }^{17}$

a) Housing scheme where its construction activities have been terminated for a period of more than one (1) year after the period which the developer shall complete the construction of the housing project is over (the completion period of the housing project is stated in the Regulations of Housing Developers (Control and Licensing) 1982 and $1989 \mathrm{viz}, 24$ months for ordinary houses and 36 months for flats); or

b) if the construction works on site of the project has not been commenced, one (1) year after the execution of the sale and purchase agreement between the purchasers and the developer concerned and the purchasers had paid the $10 \%$ deposit. Under these circumstances the project is also deemed to be an abandoned project.'

Rodziah Idris, Projek Perumahan Terbengkalai: Sebab, Kesan dan Cadangan Mengatasinya, Latihan Ilmiah Ijazah Sarjana Muda Undang-Undang, Universiti Malaya, 1990, p. 17. However, according to Zulfakar Rahmat, the definition from the Ministry of Housings and Local Government on abandoned housing projects before 1990 was 'A scheme where all activities on the site of development project have been stopped or abandoned for one (1) year or more after the expiry of sale and purchase agreement.' Zulfakar Rahmat referred to Idris Mamat, Projek Perumahan Terbengkalai: Satu Masalah Yang Memerlukan Pengorbanan Semua Pihak, Ministry of Housing and Local Government, Kuala Lumpur, 1989. 
Further, there is another definition of the same in 1988 (the 1988 definition), which reads as follows: ${ }^{18}$

'A housing scheme where its activities on site of the housing project were stopped for a duration of one year, passing beyond the required period within which the developer shall have to complete the project thereof, according to the sale and purchase agreement executed by the developer and the purchasers.'

\section{LEGAL ANALYSIS AND CRITICAL EXAMINATION OF THE DEFINITION}

It is submitted that these various definitions of abandoned housing project may lead to the difficulty of classifying the housing projects as abandoned housing project and may cause further confusion on the part of the developers and the purchasers especially in regard to managing and handling as well as reviving housing projects which are deemed to be abandoned housing projects.

The below analysis and elaboration are meant to explain and discuss the meaning and its scopes and perimeters of the above various definitions of abandoned housing project in Peninsular Malaysia.

\section{THE 2006 DEFINITION}

a) Construction activities on site of the housing construction project have stopped for 6 (six) months or more consecutively, after the expiry of the Sale and Purchase Agreement executed by the developer and the purchaser or;

18 Division of Supervision and Enforcement, Working Paper for Overcoming the Problem of Abandoned Housing Projects throughout the Nation, Ministry of Housing and Local Government, $13^{\text {th }}$ April, 1988, which was cited by Suhaimi Mohd, Projek Terbengkalai: Masalah dan Penyelesaiannya Dalam Negara Masa Kini, Latihan Ilmiah Sarjana Muda Undang-Undang, Universiti Kebangsaan Malaysia, 1992, p. 4. 
b) The developer has been put under the control of the Official Receiver and the Housing Controller is of the opinion that such developer cannot duly proceed with the execution of its obligations as a developer. ${ }^{19}$

\section{ELABORATION}

It is submitted that the meaning of the above definition, is as follows:

\section{THE FIRST LIMB}

A housing project is deemed abandoned when:

The sentence '... after the expiry of the Sale and Purchase Agreement ...' means after the expiry of the statutory completion period (24 or 36 months), after the completion period for the development of the landed property (24 months) or flat (36 months), the developer terminates the construction works of the project for six(6) months or more than six (6) months.

However, the following situations shall not be considered as abandoned housing project:

1) The sentence '.. after the expiry of the Sale and Purchase Agreement ...' means after the expiry of the statutory completion period (24 or 36 months), if the above termination of works occurred less than six (6) months after the completion period (24 or 36 months); and,

2) The sentence '....after the expiry of the Sale and Purchase Agreement ...' means after the expiry of the statutory completion

$19 \quad$ A Ministry of Housing and Local Government, Laporan Senarai Projek Perumahan Terbengkalai Dari Tahun 1990-Jun 2005 (List of Abandoned Housing Projects From Year 1990-June, 2005), 2006, p. 1. This is the current definition of 'abandoned housing projects.' 
period (24 or 36 months), if the developer stops and terminates the works, regardless of the duration, before the expiry of the completion period (24 or 36 months), the development of the project although terminated mid-way or in the mid-stream of it.

\section{THE SECOND LIMB}

It is submitted the following situation shall render a housing project to be abandoned:

The developer has been wound up and put under the control of the Official Receiver, irrespective of whether this occurs during the course of the development within that completion period ( 24 or 36 months) or beyond the completion period ( 24 or 36 months) and that the Housing Controller is of the opinion that the developer could not fulfill his statutory duties as developer as required by Act 118 and administrative duties as required by MHLG.

Nevertheless, it is submitted that the following situations shall not cause, abandonment:

1) A project shall not be deemed abandoned if any of the above (situations in the second limb) does not happen concurrently. For example, the developer has been wound up and put under the control of the Official Receiver but the Housing Controller is still of the opinion that the developer has the capability to fulfill its statutory duties and administrative duties, as developer. The statutory duties are those duties as prescribed in sections 7 (duties of a licensed housing developer), 7A (licensed housing developer to open and maintain Housing Development Account), 7B (licensed housing developer for the purpose of section 8, 8A 11 and 12), 8 (arrangement or agreement affecting the business of a licensed housing developer), 8A (statutory termination of sale and purchase agreement) and 9 (audit) of Housing Development (Control and Licensing) Act 1966 (Act 118). In this situation, the project shall still not be an abandoned housing project. On the other hand administrative duties, are duties which have been 
imposed by MHLG to ensure efficiency and good practices for the housing development activities and to protect the interests and rights of stakeholders, such as requirement to fill in a periodic specified form in a computerized system indicating the progress development stages;

2) Similarly, in the event, even in the opinion of the Housing Controller, a developer is not capable of carrying out the statutory or administrative duties as a developer, but the developer has not yet been wound up. The project shall still not be deemed abandoned;

3) As long as the developer has not been wound up, i.e even though the process of winding up has been initiated, ranging from the moment of the issuance of the sealed copy of the judgment debt order until before the order of winding up made by the court, the housing project shall not be called abandoned, until and unless winding up order has been issued by court and that the developer has been put under the control of the Official Receiver; and

4) Even where a housing developer has failed to meet any or all of the statutory duties as prescribed in Act 118 or administrative duties, but it does not stop the construction works for the project, the housing project so carried out shall not tantamount to an abandoned housing project.

\section{ISSUES}

First and foremost, the sentence in the first limb is rather confusing, when it states '....after the expiry of the Sale and Purchase Agreement (S\&P) executed by the developer and the purchaser.' This is because, this sentence does not carry any meaning and seems absurd that the sale and purchase agreement has an expiry period. It is thought the sentence should be written as follows-'the expiry of the statutory completion period for the development of the purported housing project (24 or 36 months, as the case may be).'

Secondly, a question can be raised, can a housing project be deemed as an abandoned housing project, if the termination of the works 
does not occur 'consecutively' but rather happens at regular intervals'on and off' (not consecutive) for some or considerable durations of time, beyond the mandatory and statutory period of 24 or 36 months, as the case may be? It is submitted, this loophole could warrant the abuse of the above definition, in that, the defaulting developer could say that, even though there are termination of works on sites of the housing projects, yet these terminations do not occur for six (6) or more months 'consecutively,' but rather 'terminated at regular intervals' (on and off).

Thirdly, as regards the second limb, it is submitted that, when a company is put under the control of the official receiver, it means that the company has been wound up. The official receiver shall then take over the management of the company and settle the debts owed to the creditors. It should be noted that, the process of winding up can take considerable time to be fruitful. It involves a lot of substantive and procedural laws. These range from the moment the company receives the petition for winding up until the order of winding up is issued by the Court. In between, there would be many applications involving diverse legal issues. So, from the moment the company receives the petition until the order of winding up can be issued, the final outcome may take years. The duration may be much longer, in cases where there are too many applications to set aside the orders issued and applications made by the defaulting developers, solely for the purpose of 'bidding time' and this raises the possibilities for tampering with and hiding evidences. In the meanwhile, the purchasers suffer a lot of troubles including, impossibility of occupying the houses so purchased and payment of monthly installment to their respective financiers with the possibilities of being made bankrupt by their financiers. This is compounded by the 'headaches' caused by the cunning and sneaky defaulting developers who intentionally mislead and confuse the purchasers. Once the developer companies have received the petition, it would be more prudent that MHLG and the purchasers shall have the pre-emptive power to take over the projects for rehabilitating them as soon as possible.

Fourthly, what if the said developer company has been wound up and is put under the control of the approved liquidator? Does this situation also fall under the definition of the control of the Official Receiver, partly warranting the project being considered abandoned?

In the winding up of a company, an approved liquidator shall have to be appointed. An approved liquidator according to section 4 of the Companies Act 1965 (CA) means 'an approved company liquidator 
who has been approved by the Minister under section 8 as a liquidator and whose approval has not been revoked.' Accordingly, any person can become an approved liquidator provided he is a company liquidator and has applied to the Minister of Finance to become an approved liquidator for the purpose of the CA, subject to the provisions in section 8 of the CA. ${ }^{20}$

The powers and duties of the approved liquidator are provided in section 236 (1)(2) of the CA. These powers are however subject to the direction of the Court or of the committee of inspection. ${ }^{21}$ These powers are, basically to run the affairs and businesses of the company for the purpose of settling all debts to the creditors-secured and unsecured, and carrying out all necessary and incidental duties as far as they deem fit and necessary as directed by the Court.

The appointment of an approved liquidator for the purpose of carrying out the above functions and powers is subject to the order of winding up. (section 227(1)). The appointment of the Official Receiver $(\mathrm{OR})^{22}$ is only as a provisional liquidator pending the appointment of the approved liquidator by the court. The appointment of OR as the approved liquidator is only made by order of the court, subject to the provisions in section 227(3)(4)(5)(6)(7) of the CA.

20 Section 8 of the CA generally prescribes the conditions that the company auditors and liquidators may be approved by the Minister of Finance for becoming the approved liquidator.

21 Committee of inspection may be appointed by the liquidator either on its motion or on the request of the creditors and contributories. The composition of the members of the committee is subject to section 242, where, inter alia, shall consist of creditors and contributories of the company or persons holding general power of attorney from creditors or contributories; or.... If there is disagreement on the appointment of the committee or on its composition, the Court shall have the power to decide the matter as it thinks fit. See section 241(1)(2). It is submitted that, the purpose of the appointment of such committee is to assist the liquidator in the execution of his duties.

22 According to section 4 of the Companies Act 1965 (Act 125), 'Official Receiver’ means the Official Assignee, Deputy Official Assignee, Senior Assistant Official Assignee, Assistant Official Assignee, Bankruptcy Officer and any other officer appointed under the Bankruptcy Act 1967. 
Thus, it is submitted that the sentence 'under the control of the Official Receiver' in the above definition, needs to be corrected. This is because, the appropriate word would be 'under the control of the approved liquidator, not 'the Official Receiver' as the approved liquidator will include the company auditor appointed under section 8 of CA or the Official Receiver as well, pursuant to section 277(3)(4)(5)(6)(7) of the CA. To hold only the 'Official Receiver' in the definition would mean, it is submitted, absolves the a housing development carried out by a developer company under the control of the approved liquidator.

Thus, it is submitted that the correct definition should be '...the developer has been put under the control of the Approved Liquidator ....'

Further issues are, relating to the failure of the above definition, are as follows:

1) Where the developer company is under receivership due to default of the developer company to repay the debts under the deed of debenture. The developer company has no ability and power to run its own business and affairs. It is subject to the control of an appointed receiver and manager under the deed of debenture, to administer and manage the developer company and their business towards settling all the debts owed to the debenture holders and other secured and unsecured creditors pursuant to the deed of debenture and provision in the CA - section 191(1), section 292(1)(a)-(f), section 292(3), section 295(5) of the Companies Act 1965 or other duties as directed by the Court pursuant to section 183(3)(4) of the CA;

2) Where the housing developer is either a body of persons or an individual person or a firm (partnership) or a society or cooperative society. A developer is not necessarily a company (an incorporated and separate legal entity), but also may include the former parties. ${ }^{23}$ Thus, situations where these parties may be regarded as ceasing to exist or incapable of managing their (Licensing and Control) Act 1966 (Act 118) and Schedule A-Application For A Housing Developer's Licence, of the Housing Development (Control and Licensing) Regulations 1989. 
own affairs but subject to other's control pursuant to the provisions of the related statutes such as the Bankruptcy Act 1967(Act 360), the Societies Act 1966(Act 335), the Co-operative Societies Act 1993(Act 502) and the Partnership Act 1961 (Act 135), then in this situation their housing projects shall too be so deemed as abandoned.

Further, despite the existence of the administrative definition of abandoned housing projects in Peninsular Malaysia, the given definition always changes from time to time and from year to year, resulting in certain problems of categorizing the 'problematic projects' whether they are truly abandoned or otherwise or merely a 'late' project ${ }^{24}$ or a 'sick' project, ${ }^{25}$ which would warrant different legal or non-legal actions and treatment for addressing them by MHLG, purchasers and other housing parties. The frequent-changing-definitions of abandoned housing projects, which may result in different interpretations and meanings, can be illustrated as follows. For example, on the year 2000 Definition, which reads: ${ }^{26}$

a) Construction and development works on site of the project, has been terminated for the preceding 6 months or more. Such termination has either occurred consecutively or occurred during the period within which the project shall be completed or beyond

$24 \quad$ 'Late Project' means, housing project which has not been completed within the statutory completion period (24 or 36 months), but passing beyond it. However, this project is not regarded as abandoned housing project, until it has triggered off the abandoned housing project's definition. This information was derived from an interview with Encik Ahmad Subki bin Nusi, Inspector in the Division of Enforcement and Supervision, MHLG on $11^{\text {th }}$ February, 2007. In Malay language this project is called 'Projek Sakit.' This project means, project where its housing development and construction progress is retarded and not smoothly done according to the schedule and plan initially projected. This information too was derived from an interview with Encik Ahmad Subki bin Nusi, Inspector in the Division of Enforcement and Supervision, MHLG on 11 ${ }^{\text {th }}$ February, 2007.

26 Ministry of Housing and Local Government, Senarai Projek Perumahan Terbengkalai (List of Abandoned Housing Projects)1999, 2000, p. 1. 
the required completion period. Completion period means the period within which the developer has to complete the construction of the housing units. For the landed property, the completion period is 24 months calculated from the date of the sale and purchase agreement being executed, whilst for flats the completion period is 36 months from the date of the execution of the sale and purchase agreement; or

b) Within the said duration of 6 months, the developers concerned had been wound up and has been put under the control of the Official Receiver and the Housing Controller is of the opinion that a particular housing developer has failed to carry out their obligation as a developer.

\section{ELABORATION}

The above definition, shall cover the following situations:

\section{The first limb:}

'Construction and development works on site of the project, has been terminated for the preceding 6 months or more. Such termination has either occurred consecutively or occurred during the period within which the project must be completed or beyond the required completion period. Completion period means the period within which the developer has to complete the construction of the housing units. For the landed property, the completion period is 24 months calculated from the date of the sale and purchase agreement being executed, whilst for flats the completion period is 36 months from the date of the execution of the sale and purchase agreement'

Under the following situations, based on the above definition, a housing project shall be considered abandoned when: 
1) The developer abandons the construction works for six (6) months or more during the duration period for the completion of the housing development either 24 months or 36 months, as the case may be.

2) The development works had not been completed within the required duration period for completion period, but passing beyond it without full completion and later the developer abandons the works for the duration of six (6) months or more, consecutively or otherwise.

3) The developer abandons the projects intermittently and at regular intervals (not consecutive), if accumulated the intermittent period of abandonment amounts to six (6) months or more during the duration for the required statutory completion (24 or 36 months) or after it.

The situation below, it is thought, shall not be considered an abandoned housing project:

The developer who abandons the construction works for less than six (6) months during the duration for completion of the housing development.

\section{The second limb:}

'Within the said duration of 6 (six) months, the developers concerned had been wound up and has been put under the control of the Official Receiver and the Housing Controller is of the opinion that a particular housing developer has failed to carry out their obligations as a developer'

Based on the second limb, the situation below shall be considered as an abandoned housing project:

The developer company has been wound up by the court and it has been put under the control of the Official 
Receiver resulting in its affairs, management and business subject to the direction and management of the Official Receiver.

However, in the following situations, a housing project shall not be considered abandoned:

a) The developer has not yet been wound up by the court and it has not been put under the control of the Official Receiver, even though there is proof as to the insolvency of the developer company or it is still in the course of the winding up proceedings; and,

b) Even though the developer has been wound up and has been put under the control of the Official Receiver, but the Housing Controller is still of the view that the developer company is still capable of fulfilling the statutory duties and administrative duties of a developer.

There are certain difficult issues, which the Year 2000 Definition brings. For instance, the sentence 'within the said duration of 6 months...' in the second limb to the year 2000 definition could be confusing. Certain questions can be raised in this respect, viz:

1) Whether 'the said duration of 6 months' should commence from the date of the sale and purchase agreement or others?

2) Is there any difference if the said duration of 6 months falls within any part of the statutory completion period (24 or 36 months) (for example it may fall in the early or in the middle or at the end of that completion period)?

3) Should that duration of 6 months be consecutive or otherwise (intermittently)?

4) What about if the housing developer is wound up after that duration of six (6) months (consecutively) from the date of the sale and purchase agreement having been executed? 
5) What is the position, if the developer is wound up at any time within the statutory completion period, and then being subject to the control of the Official Receiver?

It is difficult to answer the above questions but it is submitted, to simplify the matter, and to make it clear, the sentence 'within the said duration of 6 months' in the above definition is not necessary. To avoid any confusion, it is submitted, the sentence 'within the said duration of 6 months' should be rephrased to be 'at any time within the statutory completion period.' Thus, at any time within the statutory completion period (24 or 36 months), if the developer company is wound up by court and subject to the control of the Official Receiver, the housing project undertaken shall be considered abandoned. It should be noted that, the fact that a developer company is wound up and subject to the control of the Official Receiver is not sufficient to constitute its housing project abandoned. There must be in addition thereto, based on the view of the Housing Controller, that such wound up developer company, has failed to carry out statutory duties of a developer pursuant to Act 118 or administrative duties. This is because there is the word 'and' in the second limb to the year 2000 definition.

Thus, based on the above illustration, there is an issue of lacking of certainty. Even on part of the Division of Enforcement and Supervision, Ministry of Housing and Local Government (MHLG) itself, there are different kinds of definitions (definitions issued in 2000, prior to 2000, before 1990s and the 1988's definition) on the meaning of 'abandoned housing projects.' These definitions are different, although they came from one source i.e MHLG. Probably, it is submitted, because these definitions had and have been issued at different intervals of time period and involving different situations and circumstances, thus these different situations and circumstances have warranted their differences. However, what can be concluded is that these definitions are and were issued, at least, to facilitate the administration and management of the Ministry in facing and settling the problems relating to abandoned housing projects and for the purpose of categorization of the problematic housing projects.

Thus, the above highlighted issues have to be considered to formulate a better definition of abandoned housing projects by the Division of Enforcement and Supervision, MHLG so as to include and cover them as well as to address the lacunae hitherto identified. 


\section{CASE LAW}

There are reported and unreported cases which highlight occurrences of abandoned housing projects. However, it is dismal to note that, all these cases have not included the 'legal definition' of abandoned housing project. It is perceived that, judges in these cases, only accepted the concession from the litigant parties that the housing projects involved in their disputes were 'abandoned housing projects' without any confirmation from MHLG or carried out any legal analysis over the matter. These cases are, for example:

1) Xavier Kang Yoon Mook v Insun Development Sdn Bhd ${ }^{27}$ (the plaintiff purchaser succeeded in claiming late delivery damages. Abandoned housing project revived with the help from TPPT, Bank Negara);

2) Mahfar bin Alwee $v$ Jejaka Megah Sdn Bhd \& Anor ${ }^{28}$ (the site for the housing project was sold off by the chargee bank on default of the chargor developer in repayment of the bridging loan);

3) Perwira Habib Bank Malaysia Berhad v Cheong Teng Kong $\&$ Others $^{29}$ (liability of the guarantor to the bridging loan borrowed by the borrower developer whose housing project was abandoned);

4) Bunga Nominees Sdn Bhd v Abdul Jabbar Majid \& Ors ${ }^{30}$ (application by the purchaser for order of specific performance and damages in abandoned housing project against the developer and application for injunction against the receiver and manager from selling off the charged property);

$\begin{array}{ll}27 & \text { [1995] MLJU 46; [1995] 2 CLJ } 471 . \\ 28 & \text { [2004] MLJU 107. } \\ 29 & \text { [2003] MLJU 426. } \\ 30 & {[1995] \text { MLJU 79; [1995] 3 CLJ } 224 .}\end{array}$


5) Liew Jui Hua \& Ors $v$ Johor Property (M) Sdn Bhd ${ }^{31}$ (application by the purchaser to wind up the abandoned housing developer for failure to settle the late delivery damages);

6) Credit Corp (M) Bhd v Hasmah bte Salleh \& Ors ${ }^{32}$ (action for the recovery of money lent by the end-financier against the defaulting purchaser borrower in an abandoned housing project was statute barred);

7) Pilecon Engineering Bhd v Remaja Jaya Sdn Bhd ${ }^{33}$ (the court allowed the application of the receiver and manager to rehabilitate the abandoned housing project and sustained the application to wind up the housing developer company by the unsecured creditor);

8) Loh Hoon Loi \& Ors v Viewpoint Properties (Sabah) Sdn $B h d^{34}$ (involved issues on application by the purchaser to take action without having to receive consent from the lender bank for an injunction to restrain the defendant abandoned housing developer from disposing the land);

9) Kang Yoon Mook Xavier v Insun Development Sdn Bhd ${ }^{35}$ (The court allowed the application of the aggrieved purchaser for the late delivery of damages calculated from the date of the purported delivery of vacant possession until the date of the termination of the sale and purchase agreement in an abandoned housing project);

10) Penang Development Corporation v Teoh Eng Huat \& Anor ${ }^{36}$ (issues on the contractor liability for the delay caused, resulting in the purported housing project being abandoned);

$\begin{array}{ll}31 & {[1996] \text { MLJU 454. }} \\ 32 & {[2004] 4 \text { MLJ 550. }} \\ 33 & {[1997] 1 \text { MLJ 808; [1996] 1 LNS } 105 .} \\ 34 & {[1995] \text { 4 MLJ 804. }} \\ 35 & {[1995] 2 \text { MLJ 91. }} \\ 36 & {[1993] 2 \text { MLJ 97. }}\end{array}$


11) Hongkong and Shanghai Banking Corporation Ltd $v$ Kemajuan Bersatu Enterprise Sdn Bhd ${ }^{37}$ (The developer company was in the course of winding up by the creditor, where later a provisional liquidator was appointed, for the purpose of carrying out the rehabilitation, financed by a loan from TPPT, Bank Negara to revive the abandoned housing project); and,

12) Aw Yong Wai Choo \& Ors v Arief Trading Sdn Bhd \& Anor ${ }^{38}$ (A joint venture housing development between the defendant developer and the Perak State Economic Development Corporation, where later the project was abandoned and had to be rehabilitated by the Perak SEDC and the purchasers had to top-up some additional moneys due to changes in the specifications to the purported housing units);

\section{SUGGESTION AND CONCLUSION}

It is the author's submission, that a legal and official definition of abandoned housing project be adopted by the government, especially, the Division of Supervision and Enforcement, MHLG and be provided in Act 118, for the purpose of achieving the above highlighted objective and to avoid possible problems, legal or non-legal, as illustrated in the above discussion. It is perceived that the policy of the court of not referring and relying on the definition as provided by MHLG, would to a certain extent cause a chaotic meaning that deviates from what has been defined by MHLG being the authority and regulatory body in the housing development industry in Peninsular Malaysia. On part of MHLG, based on the above analysis, it is submitted that the definition given has some lacunae and loopholes, warranting it to be improvised and improved on account of what the author has listed and explained above. 